\title{
Social responsibility and the concept mix in marketing
}

\author{
K. Bhowan* \\ Department of Business Administration, University of Natal, King George V avenue, Durban, 4001 Republic of South Africa \\ W.A.A. Maguire \\ Department of Accountancy, University of Natal, King George V avenue, Durban, 4001 Republic of South Africa
}

Received I/ June 1987

\begin{abstract}
Levitt's famous article, 'Marketing Myopia' (1960), led to widespread acceptance that a marketing orientation is superior to a product orientation and brought the marketing concept to greater prominence. Writers have tended to present the discussion of fundamental concepts in marketing as an historical progression culminating in the marketing concept which is then presented as the ideal orientation, with universal application, for the formulation of an appropriate marketing philosophy. Over the last ten years or so, several writers have questioned this notion; in particular, the importance of an emphasis on product has been stressed. Another matter which has received some attention in the marketing literature is the impact on marketing philosophy of the pressure on firms to behave in a socially responsible manner. The outcome has been the incorporation of this dimension in the marketing concept. In this paper, the authors point out that the selection of marketing concepts by a firm is influenced by the nature of the firm and the conditions prevailing in its environment; the marketing concept is not an automatic choice and it is not appropriate under all circumstances. They argue turther that a firm may be better equipped by adopting a marketing philosophy which draws on two or more concepts and that such a 'hybrid' philosophy is more likely to explain the way in which firms shape their marketing philosophy in practice. Under current conditions, all firms are required to consider their stance on social responsibility in formulating strategy. As marketing philosophy is central to strategy formulation, the societal dimension should feature in it; the authors accordingly suggest that this dimension should be incorporated into any of the fundamental concepts comprising a firm's marketing philosophy. This contrasts with suggestions made to date which appear to be limited to the marketing concept.
\end{abstract}

Levitt se beroemde artikel, 'Marketing Myopia' (1960), het daartoe gelei dat algemeen aanvaar is dat 'n bemarkingsoriëntasie belangriker is as ' $n$ produkoriëntasie, en het die bemarkingskonsep meer na vore gebring. Skrywers is geneig om die bespreking van fundamentele konsepte in bemarking voor te stel as in geskiedkundige progressie wat in die bemarkingskonsep kulmineer, wat dan aangebied word as die ideale oriëntasic, met universele toepassing, vir die formulering van 'n gepaste bemarkingsformule. Verskeie skrywers het die afgelope tien jaar hierdie begrip bevraagteken; dic belangrikheid van produknadruk is veral beklemtoon. 'n Ander saak wat aandag geniet in bemarkingsliteratuur, is die impak van die druk op firmas om op 'n sosiaal verantwoordelike manier op te tree. op bemarkingsfilosofie. Die uiteinde hiervan was die inlywing van dié dimensie in die bemarkingskonsep. Die skrywers wys in hierdie referaat daarop dat die keuse van bemarkingskonseptc van 'n firma beïnvloed word deur die aard van die firma asook omgewingsomstandighede; die bemarkingskonsep is nie 'n outomatiese keuse nie. en is nie onder alle omstandighede geskik nie. Verder voer hulle aan dat 'n firma beter toegerus kan wees deur'n bemarkingsfilosofie te aanvaar wat op twee of meer konsepte gebaseer is en dat so ' $n$ 'hibridiese' filosofie des te beter kan verduidelik hoe firmas ' $n$ bemarkingsfilosofie in die praktyk vorm. Daar word van alle firmas verwag om hulle posisie t.o.v. sosiale verantwoordelikheid tydens strategieformulering, te oorweeg. Omdat bemarkingsfilosofie sentraal fungeer by strategieformulering behoort die maatskaplike dimensie 'n rol daarin te speel; die skrywers stel gevolglik voor dat hierdie dimensic ingesluit word in enige van dic fundamentele konsepte wat 'n firma se bemarkingsfilosofie uitmaak. Dit kontrasteer met voorstelle tot op hede wat blykbaar tot die bemarkingskonsep beperk was.

* To whom correspondence should be addressed

\section{Introduction}

The marketing concept has been advocated as the ideal if an organization is to achieve success in the marketplace. This suggests a universal prescription for all organizations and circumstances. Where writers have expressed concern about the preoccupation with the marketing concept, they have tended to argue in favour of one of the other concepts, i.e. they do not appear to have considered the possibility that a firm's marketing strategy may draw on several marketing concepts to arrive at a mix which is compatible with its mission and objectives. In this paper, new dimensions are suggested which are likely to influence a firm's marketing strategy and tactics.

Some clarification of our usage of the terms 'concept', and 'philosophy' is appropriate at this point. We will refer to the mix of concepts selected by a firm as its marketing philosophy. This usage contrasts with that of Kotler $(1983 ; 1984)$ who appears to use the terms 'concept', 'philosophy' and 'orientation' interchangeably; we suggest that our separate usage of these terms provides greater clarity. However, where a firm's strategy draws on one concept only, the distinction between the firm's marketing philosophy and the concepts on which it draws has no significance.

In this paper, we suggest that organizations are most likely to create unique marketing philosophies to achieve organizational goals. We consider the following aspects: -A firm's marketing philosophy comprising more than one fundamental concept 
-The supremacy of the marketing concept

-Variation in the level of intensity with which any one concept is applied

-The impact of social responsibility on the fundamental concepts

\section{The fundamental concepts in marketing philosophy}

Kotler (1984:16-30) lists what he describes as five 'competing concepts' under which a business may carry out its marketing activity, namely the production concept, the product concept, the selling concept, the marketing concept, and the societal marketing concept. With the exception of the last-mentioned, all of these concepts are well-recognized in the literature. The societal marketing concept is examined more closely later in this paper.

By describing the concepts as 'competing', Kotler implies that only one of these concepts may be adopted at any one time. This conception is consistent with Keith's (1960) presentation of an historical progression through a hierarchy commencing with the production concept and culminating in the marketing concept.

Recently several authors have questioned whether the advocacy of the marketing concept as the ideal philosophy under all circumstances is justified. Bennet \& Cooper (1981), Hirschman (1983) and Houston (1986) are recent representatives of this group. They suggest that one of the other concepts may be more appropriate, depending on the circumstances. We concur with this view. We argue further that a company's marketing philosophy need not be limited to one concept at any one point in time, but that it may adopt two or more concurrently to form a mix of concepts appropriate to its strategic posture.

\section{Are the other concepts implicit in the marketing concept?}

In support of the supremacy of the marketing concept, one may take the view that it incorporates the other fundamental concepts because it requires the firm to satisfy the consumer's needs and wants, to maintain consumer satisfaction, and to integrate the firm's activities with the marketing function in order to achieve organizational goals. If the emphasis is placed on satisfying consumer needs and wants, then it can be argued that once the marketer has determined what the market requires, he can use any appropriate concept to reach the customer. If, for example, the marketer establishes that a consumer needs an insurance policy but is unwilling to purchase it, then it is appropriate for the insurance company to use the selling concept to persuade the consumer to buy the insurance cover. On the other hand, if this marketer is trying to sell insurance cover to a market segment comprising potential clients with a good understanding of their insurance needs and a knowledge of products offered by rival firms, then it may be necessary to use the product concept by emphasizing say, product features which are considered superior to those of the rival firms. The foregoing suggests that the marketing concept is sufficiently broad to embrace the production, product and selling concepts. Therefore, whatever the environment of the marketplace, the marketer must choose the appropriate concept to satisfy the consumer's needs and wants.

Whilst the above argument may appear reasonable, it breaks down if we consider the fundamental differences between the marketing concept and the selling concept. Under the selling concept the marketer develops a product without due regard for the requirements of the market place; having made the product, the firm uses aggressive selling to dispose of its products. Under the marketing concept, the firm establishes what consumers want before developing the product. These are thus two different concepts. Each of the four concepts has a different orientation; it is therefore erroneous to suggest that the marketing concept implies all the other concepts and it may be advantageous to accept that each concept offers a distinct and separate approach to the market.

\section{The impact of social responsibility on the fundamental concepts}

The authors of most financial management texts point out that profit-seeking entities are now required to pursue wealth maximization subject to socially imposed constraints (see, for example, Brealey \& Myers, 1984; Brigham, 1985; Weston \& Copeland, 1986). This recognises the impact of other concerns such as the welfare of employees and the public at large, i.e. the social responsibility of business. This has been broadly defined by Andrews as: ' ...... The intelligent and objective concern for the welfare of society that restrains individual and corporate behavior from ultimately destructive activities, no matter how immediately profitable, and leads to the direction of positive contributions to human betterment, variously as the latter may be defined'. (Andrews, 1971 as cited in Steiner, Miner \& Gray, 1982:80).

As is pointed out by Steiner, Miner \& Gray (1982:84), 'the great bulk of socially responsible actions taken by corporations is mandated by market conditions and government edict'. They observe further that 'corporations, especially the larger ones, have sought to respond appropriately on a voluntary basis to the legitimate demands of various constituents'. They add that large companies and those that exert power over individuals and communities for other reasons, tend to attract the interest of society. Whatever the impetus, the ethos of a company will determine whether its concern for social responsibility extends beyond that dictated by legislation and market conditions. The distinction between 'proactive' and 'reactive' is relevant here. Response to legislation can only be described as reactive, whereas appropriate voluntary response to societal issues before they have been championed by pressure groups is truly proactive.

A company's ethos impacts directly on strategy formulation; social responsibility is thus a strategic variable. The marketing philosophy adopted by a company is also a strategic variable.

If a firm recognizes its social responsibility, one would 
expect this to be reflected in its marketing philosophy. Kotler (1984:29) has given effect to this in his 'societal marketing concept', which is intended to incorporate social responsibility and so supplant the marketing concept. If each of the concepts is regarded as separate and distinct, and the social responsibility of business is generally accepted, it follows that this dimension should be incorporated into each of the concepts; its inclusion should not be restricted to the marketing concept alone. To the societal marketing concept should be added the societal production concept, societal product concept, and societal selling concept. A brief consideration of each of these modified concepts follows.

\section{The fundamental concepts modified}

On acceptance of social responsibility, it may be suggested that the fundamental concepts should be modified to reflect this social dimension. Apparently in conformity with the supremacy accorded the marketing concept, this dimension has been formally recognized in that case only (Kotler,1984).

\section{The societal marketing concept}

The 'societal marketing concept' is a term coined by Kotler (1984:29) to describe a 'new concept to revise or replace the marketing concept'. He prefers this term to the 'human concept', 'intelligent consumption concept', and 'ecological imperative concept' suggested by Dawson (1969), Rothe \& Benson (1974), and Fisk (1973) respectively (as cited by Kotler, 1984:29). He defines it as follows: 'The societal marketing concept holds that the organisation's task is to determine the needs, wants, and interests of target markets and to deliver the desired satisfactions more effectively and efficiently than competitors in a way that preserves or enhances the consumer's and society's well being'.

Two main points are made in this paper. First, that companies are most likely to develop a contingency approach to the marketing philosophy reflected in their strategy and tactics. As mentioned above, this point is well made by Houston (1986). Second, that the concepts are not mutually exclusive, i.e. a company's marketing philosophy at any one time may incorporate elements of two or more of the established concepts. In order to explore the applicabiiity of this to the societal marketing concept, it is necessary to examine Kotler's definition more closely. Kotler's extensions to the marketing concept are clearly revealed by the words italicized (our emphasis): 'The societal marketing concept holds that the organisation's task is to determine the needs, wants, and interests of target markets and to deliver the desired satisfactions more effectively and efficiently than competitors in a way that preserves or enhances the consumer's and society's well being.

Reference to Kotler's example of a company which achieved sales and profit gains through adopting and practising the societal marketing concept is instructive: 'Giant Food, Inc., a leading supermarket chain in the Washington D.C. area, took the initiative and introduced unit pricing, open dating, and nutritional labeling. They assigned home economists to their stores to help consumers buy and prepare food more intelligently. They invited Esther Peterson, formerly the President's advisor on consumer affairs, to join the board of directors and provide guidance on consumeroriented retailing. According to a spokesman for the company, "These actions have improved Giant's goodwill immeasurably and have earned the admiration of eaders of the consumer movement"'.

We suggest that this example in no way illustrates the application of the extensions to the marketing concept. Consumer environmental and similar groups have been successful in bringing pressure to bear on the legislation and on big business to consider societal issues in the way in which business is conducted. Where such pressure results in new legislation or the amendment of existing legislation, a responsible company (i.e. assuming that compliance with the law forms part of the company's ethos) will comply with those requirements. Such compliance does not constitute a response to societal concerns. Giant Foods had apparently gone further than this, the corporation was responding to consumer interest issues which were not embodied in law. However, while it can be argued that the management was motivated by the well-being of the consumer or the society, there is nothing in their response which is inconsistent with an intelligent application of the marketing concept. It is suggested that the consumer groups were by this stage sufficiently successful for consumers, at least a significant body of consumers, to seek unit pricing, open dating and nutritional labeling and home economists' assistance as described in the example. In other words, the response mentioned could have been expected of a forward-thinking company which is ready to exploit competitive opportunity; it need not be explained by the extensions to the marketing concept which appear in Kotler's definition.

The distinction between 'proactive' and 'reactive' may be useful here. Response to legislation can only be described as reactive. It is a moot point as for whether Giant Foods was proactive in its marketing initiative; certainly, it estabiished itself as a leader in responding to the consumer movement, but it was nevertheless reacting to environmental developments. For a company to be seen to be promoting the societal marketing concept, it would have to be proactive in the sense of identifying and acting on consumer and societal issues before they had been identified and championed by pressure groups.

We conclude that the societal marketing concept is by no means pervasive. The requirements for acting fully in compliance with the concept are rigorous; we contend that corporate action which appears to conform with the societal marketing concept can generally be explained in terms of the marketing concept and/or in terms of the now generally accepted notion that companies should behave in a socially responsible manner. 


\section{Societal production concept}

The production concept is applicable when the demand exceeds supply and/or where higher output lowers cost per unit and hence lowers prices resulting in market expansion. Many third world countries, and some sectors of first world countries, experience shortages of consumer goods, therefore businesses in those economies tend to be production-oriented. Where such firms take cognizance also of their social responsibility, another dimension is added, and we suggest that the relevant concept in this instance be referred to as the societal production concept.

\section{Societal product-need concept}

The marketing myopia against which Levitt (1960) warned so strongly is avoided by focusing not only on the product but also on changing trends in the environment. This could be referred to as conforming with the product-need concept as defined below.

The product-need concept holds that the consumer will purchase a product that offers value for money and satisfies his needs and wants better than alternative product offerings. If the societal dimension is added, the marketer's task is to strive continuously to improve his product while, ensuring that society's interests are safeguarded. By adhering to the societal product-need concept, a firm takes into account society's interests in a proactive manner as explained above.

The term 'product-need' suggests that the marketer has constantly to monitor what the market place requires in terms of the basic needs satisfied by the product. Thus an awareness of alternative technologies capable of satisfying a particular need is essential.

This concept probably applies most closely to firms with access to advanced technology. Hayes \& Abernathy $(1980: 71)$ observe that many consumers are unable to conceive of products that are radically different because they 'often define products in terms of existing products, processes, markets and prices'. Edward de Bono (1977:28) points out that 'it may be so difficult to escape from a dominant idea that it becomes impossible without outside help' and this is illustrated by his reference to the first motor cars as 'distortions' of the horse carriage(1977:126). German manufacturers appear to operate in terms of the 'product-need' concept. According to Limprecht \& Hayes (1982), they do not automatically accept that customers know what they want and they place great emphasis on product quality, timely delivery and reliable network service.

\section{Societal selling concept}

According to the societal selling concept, some products that satisfy consumer needs are generally neither sought out nor are they purchased by consumers; they require intensive promotion through advertising, sales promotion, publicity and/or personal selling.

Examples of such products are life insurance, home safety systems and encyclopaedia sets. Firms adopting this philosophy thus place heavy emphasis on the promotion component of the marketing mix. The impact of the qualifier 'societal' here is that the intensive promotional and selling effort should exclude consumer exploitation. The responsible marketer would be expected to ensure that the product satisfies consumer needs, that it is of a high quality and that it offers good value for money.

\section{Marketing philosophy or concept mix}

We have suggested above, that the marketing concept does not subsume the other concepts, but that each remains separate and distinct. It does not follow that a firm's marketing philosophy cannot include two or more of these concepts simultaneously. Four basic concept mixes can then be identified:

- From the four fundamental concepts, one is selected - From the four fundamental concepts, two or more are selected and adopted in combination

- From the four 'societally modified' concepts referred to above, one is selected

- From the four fundamental concepts, two or more are selected and adopted in combination, together with varying degrees of the societal dimension depending on the extent to which the firm recognizes its social responsibility

In the four basic philosophies represented by the four basic concept mixes indicated above, the intensity with which each of the concepts is applied may clearly vary This can be illustrated by reference to a few examples.

Pick 'n Pay: In the convenience goods section, products are sold without personal selling, while the consumer durable goods section is specifically staffed with sales people. It also seems reasonable to conclude that the company's purchasing policy emphasizes good quality products to enhance profitability. Pick in Pay's corporate image and observed behaviour in the market are consistent with the societal marketing concept. It would appear that Pick 'n Pay's marketing philosophy is dominated by the societal marketing concept but that the product and selling concepts are employed where appropriate. This is illustrated in Figure 1.

Corobrik provides another illustration of a marketing philosophy which comprises a mix of concepts rather than being restricted exclusively to one. Corobrik is a brick manufacturer which almost has a monopoly in the Durban area. While its marketing philosophy could be expected to conform with the production concept, competition from alternative construction materials

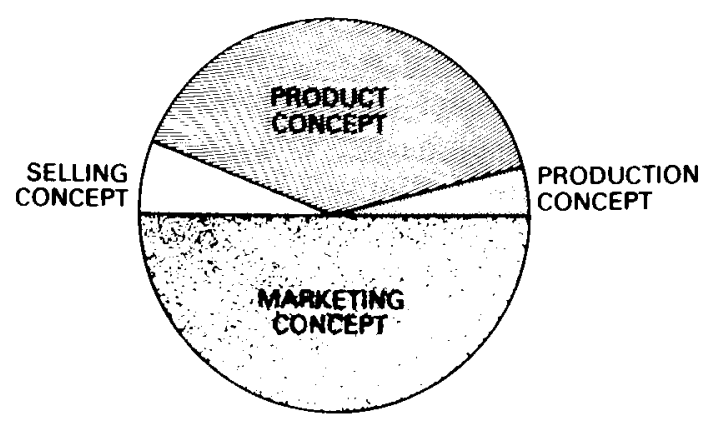

Figure 1 Concept mix of Pick 'n Pay 


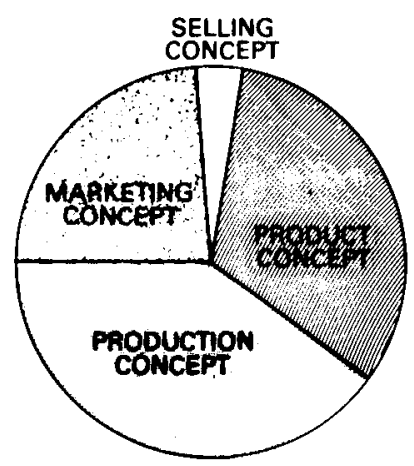

Figure 2 Concept mix of Corobrik

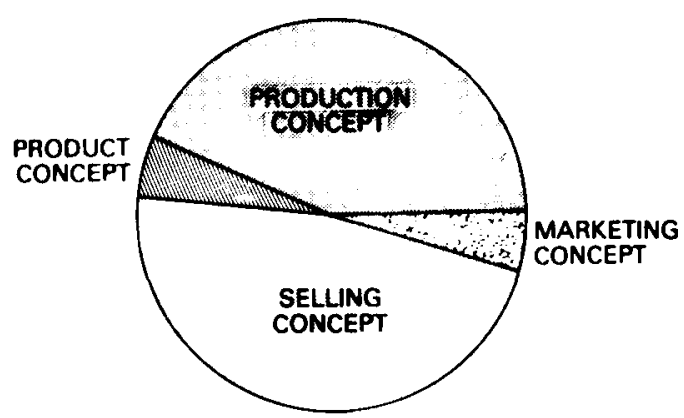

Figure 3 Concept mix of an hypothetical drug firm

requires that the company's concept mix include the marketing concept. Indeed, this appears to be borne out by the development of the maxibrick.

They may also believe that the way to counter threats from alternatives is through making bricks aesthetically more appealing than those alternatives. This strategy is an application of the product concept. Under the circumstances in which the firm operates it can be assumed that selling concept will play a small role in the firm's business philosophy.

Thus Corobrik's concept mix might look as shown in Figure 2.

To provide a contrast, we consider the marketing philosophy of an hypothetical firm which deals in illegal, hard drugs. The marketing concept may be relevant in that the firm responds to existing needs to some extent. Further, product quality cannot be entirely ignored as users would resist a product which is below a required minimum; thus the product concept has relevance here. It does appear, however, that ultimately, the user's main concern is with availability, to satisfy the addiction, and therefore production orientation is a major concern of the supplier. As important, if not the dominant concept in this instance is the selling concept; a variety of hardsell is employed without concern for the consequences. This is illustrated in Figure 3.

\section{Implications for marketing}

A move away from the idea that the marketing concept should be the dominant philosophy for all business organizations has several implications for marketers, as indicated below.
- Marketers need to establish the nature of their operating environment to establish whether they have the appropriate concept mix for the situation. Some organizations may have tended to regard the marketing concept as the only suitable philosophy. If the situation analysis suggests otherwise, it is clearly necessary to alter the philosophy accordingly.

- In the case of an organization moving away from the marketing concept towards the product-need concept, there may be a re-allocation of resources from market research to research and development. Skilful management of people is of prime importance here as such a change of emphasis may lead to interdepartmental conflicts.

- Manufacturers who produce products for several market segments may have to adopt separate marketing philosophies for different segments, depending on market conditions for each product line.

- A product may demand a change in marketing philosophy as it 'travels' through the product life cycle. It is conceivable that the product-need concept may result in a technical innovation that satisfies a latent need in the market. If a new product is successful and attracts competition, the originator of the product may have to resort to the selling concept to overcome competition during the growth phase. During the maturity phase, the marketing concept may be more appropriate and finally during the decline phase, when only a few traditional buyers continue to buy the product, a return to the product concept may be required as the customer is interested only in the availability of the product and a quality level to which that he or she has become accustomed.

\section{References}

Bennet, R.C. \& Cooper, R.G. 1981. The misuse of marketing: An American tragedy. Bus. Hor. 51-60.

Brealey, R. \& Myers, S. 1984. Principles of corporate finance. 2nd Edition. New York: McGraw-Hill. 847p.

Brigham, E.F. 1985. Financial management; theory and practice. 4th Edition. Chicago: Dryden, 1128p.

de Bono, E. 1977. The use of lateral thinking. Harmondsworth: Penguin, 141p

Hayes, R.H. \& Abernathy, W.J. 1980. Managing our way to economic decline. Harv. Bus. Rev. July-August, 67-77.

Hirschman, E.C. 1983. Aesthetics, ideologies and the limits of the marketing concept. J. Market., vol. 47. 45-55.

Houston, F.S. 1986. The marketing concept: What it is and what it is not. J. Market. vol. 50,81-87.

Keith, R.J. 1960. The marketing revolution. J. Market. Jan, vol. 24, 35-38.

Kotler, P. 1983. Principles of marketing. 2nd Edition. London: Prentice-Hall, 676p.

Kotler, P. 1984. Marketing management: Analysis, planning and control. 5th Edition. London: Prentice-Hall, 792p.

Levitt, T. 1960. Marketing myopia. Harv. Bus. Rev. JulyAugust, vol. 38, 24-27. 
Limprecht, J.A. \& Hayes, R.H. 1982. Germany's world-class manufacturers. Harv. Bus. Rev. November-December, 137-145.

Steiner, G.A., Miner, J.B. \& Gray, E.R. 1982. Management policy and strategy: Text, cases and readings. New York: Macmillan, 1153p.

Weston, J.F. \& Copeland, T.E. 1986. Managerial finance. 8th Edition. Chicago: Dryden, 1035p. 